\title{
Wanita dan e-Sukan di Malaysia: Sosialisasi dan Stereotaip Gender
}

\author{
NUR HAFIZAH YUSOFF \\ ZURINAH TAHIR \\ NOVEL LYNDON \\ NORHAFIZAH ABU HASAN \\ YUZA HAIQAL MOHD YUNUS \\ Universiti Kebangsaan Malaysia
}

\begin{abstract}
ABSTRAK
Artikel ini membincangkan mengenai stereotaip gender yang dialami oleh pemain e-sukan wanita. Isu mengenai stereotaip gender terjadi kerana e-sukan dikategorikan sebagai sukan yang didominasi oleh kaum lelaki kerana majoriti pemain terdiri daripada kaum lelaki. Bagi wanita yang memilih untuk menjadi sebahagian daripada industri e-sukan, mereka tidak dapat lari daripada elemen stigma, label dan seterusnya stereotaip hanya disebabkan gender mereka berbeza. Bagi menjawab isu ini, pendekatan kualitatif menggunakan temu bual mendalam telah dilakukan ke atas tujuh orang wanita yang terlibat aktif di dalam e-sukan. Informan tersebut dipilih melalui persampelan bertujuan dengan ciri-ciri spesifik iaitu wanita, terlibat di dalam e-sukan dan menjadi pemain bagi sesebuah pasukan/kelab e-sukan dan terlibat dalam permainan jenis berperanan berganda (MMOPRGs). Data dianalisis menggunakan analisis tematik dan dipersembahkan secara deskriptif dan naratif. Hasil kajian menunjukkan terdapat beberapa jenis stereotaip yang menjadi cabaran serta halangan kepada pemain wanita ini untuk terus berjaya di dalam kerjaya sebagai seorang professional 'gamers'. Stereotaip gender seperti wanita tidak pandai bermain MMOPGRs, komen berbau seksis serta lucah juga pernah diterima, tiada komunikasi yang baik antara pemain lelaki dan wanita dan tanggapan bahawa wanita tidak sesuai bermain permainan tersebut kerana kebanyakan permainan berganda ini bersifat ekstrem, agresif dan maskulin. Ciri-ciri permainan tersebut lebih signifikan kepada lelaki berbanding dengan wanita yang seringkali dikaitkan dengan sifat feminin. Secara tidak langsung, tanggapan seperti itu sedikit sebanyak menyekat peluang wanita untuk bergerak lebih aktif dan maju di dalam e-sukan berbanding lelaki.
\end{abstract}

Kata kunci: Wanita, e-sukan, sosialisasi, gender, stereotaip gender, sosiologi.

\section{Women and E-sports: Socialization and Gender Stereotype}

\begin{abstract}
This article discusses the gender stereotypes experienced by female athletes in e-sports. The issue of gender stereotypes arises because e-sports is categorized as 'male-dominated sport' because the majority of players are male. For women who choose to be a part of the e-sports industry, they cannot deviate from the elements of stigma, labels and stereotypes simply because their gender is female. To answered this issue, a qualitative approach using in-depth interviews was conducted on seven women who were actively involved in e-sports. The informants were selected through purposive sampling with a specific characteristic which is women, actively participating in e-sports, they also representing any of an e-sports team/club and involved in multiple role-playing games (MMOPRGs). Data were analyzed using thematic analysis and presented descriptively and narrative. The results show that there are several types of stereotypes that's has been a challenge for female players to succeed in their career as professional gamers. Gender stereotypes such as women are
\end{abstract}


not good at playing MMOPGRs, sexist and sexually explicit comments have also been received, having a difficult communication among team members especially male team members and the notion that women are not suitable to play the game because most of these games are kind of extreme, aggressive and masculine. The features of the game are more significant to men compare to women who are often associated with femininity. Indirectly, such perceptions slightly hamper the opportunities for women to be more active and progressive in e-sports.

Keywords: Women, e-sports, gender, gender stereotype, sociology of sport.

\section{PENGENALAN}

Kemajuan teknologi maklumat, internet, dan teknologi komputer pada masa kini sudah semakin pesat dan tidak asing lagi pada masyarakat Malaysia khususnya. Kemunculan platform komunikasi alternatif melalui media sosial khususnya memudahkan proses komunikasi berlaku (Mohd Azul, Za-idah \& Ali Salman, 2019). Selain kewujudan aplikasi untuk berkomunikasi, perkembangan teknologi dan digital kini turut membawa perubahan ke dalam dunia sukan. Hasilnya, tercipta permainan video, permainan komputer, dan permainan telefon pintar yang cukup menyeronokkan dan menjadi hobi kepada bukan sahaja golongan kanak- kanak malah golongan dewasa. Jika dahulu permainan video dalam talian tidak dilihat memberikan kebaikan kepada pemainnya. Walaubagaimanapun, perubahan medium permainan dalam talian juga ada kebaikannya. Hal ini kerana, platform media baharu kini juga berperanan untuk memberi pendidikan kepada penggunanya (Emma \& Nur Hazwani, 2019). Ini dibuktikan apabila permainan komputer dalam talian telah menjadi fenomena yang luar biasa di serata dunia dan mendapat pengiktirafan melalui pertandingan yang menawarkan hadiah-hadiah yang lumayan (Wagner, 2006).

Mengikut definisi, e-sukan adalah sukan berasaskan permainan komputer yang dimain oleh pemain atau gamer yang profesional dalam satu bentuk persaingan atau pertandingan rasmi antara pasukan yang difasilitasikan oleh sistem elektronik (Edward, 2013). Terdapat banyak genre permainan video popular melibatkan pertempuran yang menjadi acara dipertandingkan sebagai contoh genre Strategy Base Game, First person Shooter (FPS), Multiplayer Online Battle Arena (MOBA) dan Player Unknowns Battleground (PUBG) merupakan genre permainan video yang paling mendapat sambutan sebagai acara dalam e-sukan ini. Antara permainan melibatkan komputer yang hangat di Malaysia ini adalah permainan berasaskan strategi seperti Defense of the Ancient 2 (DOTA2) dan League of Legends (LOL). Dua permainan ini merupakan pertempuran berasaskan strategi mod arena dalam talian melibatkan sebilangan pemain yang bertempur menggunakan unit berkuasa yang dikenali sebagai pahlawan (heroes) dan dibantu oleh rakan sepasukan yang bersekutu.

Revolusi teknologi permainan komputer masa kini telah mengubah konteks atau peranan permainan digital itu sendiri disebabkan ciri atau sifatnya yang begitu interaktif menghubungkan pemain tanpa batasan secara virtual merentasi sempadan negara di mana pemain boleh berhubung dan mewujudkan komuniti golongan muda ini secara maya. Sepatutnya dengan konsep sedemikian, permainan dalam talian ini memberi ruang dan kuasa kepada pemainnya untuk mengekspresikan diri mereka (Mohd Azul \& Nurul Madiha, 2017) melalui kemahiran dan teknik di dalam satu-satu permainan yang dimainkan. Pada bulan September 2017, Presiden Mineski Events Team (MET) iaitu Kenchi Yap mengumumkan pertandingan e-sukan negara iaitu Malaysian Esports League (MESL) yang merupakan pertandingan DOTA 2 yang terbesar setakat ini di Malaysia melibatkan wang tunai RM500 ribu mendapat sambutan hangat golongan muda negara juga kepada 
pemain luar negara (Hayes, 2007). Tambahan lagi, Malaysia kini mempunyai ikon e-sukan negara yang telah menempah rekod antarabangsa seperti 'Mushi' Chai Yee Fung, 'Ohaiyo' Khoo Chong Xin, 'MidOne' Cheng Yeik Nai dan 'Ah Fu' Tue Soon Chuan yang merupakan atlet e-sukan handalan Malaysia berjaya mengharumkan nama negara di arena antarabangsa (Lee, 2015). Kebanyakan e-sukan ini dimonopoli golongan muda remaja sekitar usia 16-30 tahun. Pada 1 Mei 2015, Persatuan Sukan Elektronik Malaysia telah dilancarkan secara rasminya, sekaligus menyaksikan fokus yang lebih diberikan kepada sukan permainan elektronik di Malaysia di samping mempromosikannya. Persatuan Sukan Elektronik Malaysia atau turut dikenali sebagai eSports Malaysia (ESM) juga telah pun didaftarkan dengan Suruhanjaya Sukan Malaysia.

Walau bagaimanapun, majoriti pemain e-sukan baik di Malaysia mahupun di luar negara masih dimonopoli oleh golongan lelaki. Oleh yang demikian, e-sukan dikonsepkan sebagai 'male-dominated industry'. Tidak dinafikan bahawa terdapat sebilangan kecil wanita yang berjaya 'memasuki' industri e-sukan terutamanya di Malaysia. Namun demikian, jumlah ini masih terlalu kecil jika dibandingkan dengan pemain lelaki. Selain itu, golongan wanita ini turut menerima stereotaip gender daripada pelbagai pihak.

\section{SOROTAN KARYA}

\section{Evolusi e-Sukan}

Seperti yang dinyatakan, e-sukan merupakan sakah satu industri terbesar kini. Mengambil jumlah penajaan dan hadiah kemenangan yang lumayan. Buat pertama kali juga e-sukan telah dipertandingkan bersama-sama sukan konvensional yang lain. Misalnya di peringkat South East Asia Games (Sukan SEA), Sukan Asia dan Sukan Olimpik kelak. E-sukan mungkin merupakan satu konsep yang baharu diperkenalkan. Namun demikian, 'virtual sports' telah bermula sejak sekian lama sejak teknologi komputer tercipta dan konsol permainan diperkenalkan (Chikhani, 2015). Tennis for Two merupakan sukan virtual pertama yang diperkenalkan kepada penonton sekitar tahun 1958 (Lynch, 2016). Tennis for Two dicipta dengan memaparkan imej gelanggang tenis pada komputer dan pemain perlu mengerakkan bola tenis dengan menyentuh paparan skrin. Lebih kurang persamaan dengan permainan dalam talian di era moden kini.

Manakala, pada tahun 1967, Ralph Baer telah mencipta satu permainan yang dikenali sebagai Brown Box yang merupakan permainan dalam talian pertama yang menggunakan konsol tombol bagi mengawal permainan dan ia juga dipaparkan di set televisyen (Bradmore \& Magus, 2016). Perlawanan permainan dalam talian pertama kalinya bermula sekitar tahun 1980an yang dikenali sebagai Space Invanders Tournament (Edwards, 2013). Pertandingan ini menarik lebih 10 ribu penyertaan dan dikatakan melalui pertandingan ini yang akhirnya mencetuskan e-sukan secara perlahan-lahan. Walaubagaimanapun, permulaan besar kepada industri e-sukan sebenarnya bermula pada tahun 1998, apabila permainan StarCraft diperkenalkan. Permainan ini menggunakan kaedah permainan 'matching' yang membolehkan para pemain bermain dengan pemain yang tidak dikenali oleh mereka (Lynch, 2016). Strategi dan teknik menjadi asas penting kepada StarCraft sehinggakan ia menjadi fenomena bagi kebanyakan negara pada satu masa dahulu.

Sehingga tahun 2012, League of Legends (LOL) mengambil alih sebagai permainan dalam talian yang berpengaruh di dunia. Permainan ini dianggarkan memiliki lebih 100 juta pemain (Milne \& McDonald, 1999) di seluruh dunia dan ratusan ribu peminat turut 
mengikuti permainan ini. Tidak lama selepas LOL, MOBA pula diperkenalkan dan turut mencetuskan fenomena di serata dunia. MOBA lebih menumpukan kepada kerjasama kumpulan, peri pentingnya aspek komunikasi berkumpulan bagi merangka strategi mencapai kemenangan (Everson, 2013). Kini, lebih banyak permainan di dalam e-sukan diperkenalkan dan bukan hanya tertumpu kepada permainan aksi dan berperanan berganda semata-mata. Permainan seperti bola sepak turut tersenarai di dalam e-sukan dan lebih dikenali dengan nama FIFA 20.

\section{Perbezaan Penglibatan Gender di dalam e-Sukan}

Wanita sering menjadi subordinat di dalam sukan-sukan konvensional. Keupayaan dan pencapaian atlet wanita seringkali dibandingkan dengan atlet lelaki (Shen et al., 2016). Perkara yang sama turut berlaku di dalam industri e-sukan. Walaupun e-sukan tidak melibatkan sentuhan fizikal oleh para pemain, namun ia cukup sinonim dengan satu sukan yang agresif dan ganas. Hamari dan Sjöblom (2017) memberikan contoh Counter Strike: Global Offensive memerlukan pemain menembak mati pihak lawan bagi memenangi perlawanan tersebut. Selain itu, keseronokan memainkan sesuatu permainan dan keterujaan memenangi perlawanan atau melangkah ke 'ranking' yang lebih tinggi lebih mengujakan bagi lelaki berbanding wanita (Ray, 2004). Memenangi sesuatu perlawanan adalah matlamat terbesar bagi kebanyakan pemain e-sukan lelaki (Miller, 1996), manakala wanita tidak terlalu memikirkan mengenai menang atau kalah (Ray, 2004). Hal ini kerana wanita lebih bersifat terbuka kerana di dalam sesuatu sukan sudah pasti akan ada pihak yang akan menang dan kalah. Keterbukaan menerima kekalahan dan kemenangan juga lebih dimiliki oleh pemain wanita (Shen et al., 2016). Selain itu, kebanyakan permainan dalam talian ini direka untuk tujuan menarik minat kaum lelaki berbanding wanita. Permainan seperti MOBA, LOL dan StarCraft misalnya, adalah permainan yang berpaksikan kepada peperangan, aksi dan diselitkan dengan elemen ganas (Hamari, 2013). Ciri-ciri tersebut lebih melambangkan imej lelaki yang maskulin berbanding wanita yang feminin. Secara tidak langsung, ia menjawab persoalan mengapa lebih ramai lelaki berminat untuk menyertai e-sukan berbanding wanita.

Dari segi kebolehan bermain, wanita juga dikatakan tidak dapat menyamai keupayaan lelaki, malah mereka sendiri adakalanya tidak yakin dengan kemampuan 'skills' yang mereka ada (Shen et al., 2016). Namun demikian, isu ini wujud kerana cara pemain wanita ini belajar teknik dan kaedah di dalam permainan e-sukan (Blumberg \& Sokol, 2004). Ekoran daripada itu, Bonanno dan Kommers (2008) menyatakan bahawa tempoh masa yang dihabiskan untuk berlatih juga menjadi penyebab kenapa lelaki lebih memiliki keupayaan tinggi berbanding wanita terutamanya dalam permainan berganda (MMOPRG). Antara sebab yang mendorong pemain wanita kurang berlatih dan bermain berbanding pemain lelaki adalah disebabkan faktor ketidakpercayaan terhadap kemampuan sendiri dalam permainan e-sukan (Chan, 2008). Wanita seakan mempercayai bahawa lelaki lebih sesuai terlibat aktif di dalam permainan 'role player' kerana ia melibatkan elemen sains, matematik, kejuruteraan dan teknologi (STEM). Selain itu, dari segi hadiah yang ditawarkan juga terdapat perbezaan di antara pemain lelaki dan wanita. Ruvalcaba et al. (2018) menjelaskan lazimnya pemain lelaki dibayar gaji yang lebih tinggi berbanding dengan pemain wanita. Hal ini didorong oleh faktor lelaki lebih memiliki 'skills' dan keupayaan teknik yang lebih baik daripada wanita. Wanita juga lebih banyak memegang peranan yang pasif iaitu sebagai 'supporting players', pembantu kepada 'main players' iaitu lelaki (Shen et al., 2016). Situasi tersebut secara tidak langsung menyebabkan 
berlakunya ketidakadilan dari segi peranan di dalam permainan dan sudah tentu juga dari sudut pembayaran gaji pemain.

\section{Stereotaip Gender di dalam e-Sukan}

Penglibatan di dalam industri sukan yang didominasi oleh lelaki baik di depan mahupun di belakang tabir, ia secara tidak langsung telah menyebabkan berlakunya stereotaip gender terutamanya bagi pemain wanita. Hal ini kerana, wanita merupakan golongan minoriti di dalam industri e-sukan. Hasil kajian Yee (2006) mendapati bahawa sebanyak $86 \%$ pemain MMORPG adalah terdiri daripada pemain lelaki dan bakinya adalah pemain wanita. Wanita yang terlibat di dalam e-sukan adakalanya berhadapan dengan isu sexism dan gangguan seksual (Ruvalcaba et al., 2018). Imej wanita di dalam sesuatu permainan seperti Mobile Legends, PUBG dan Dead or Alive memaparkan wanita sebagai seorang yang seksi iaitu berpakaian baju renang atau pakaian yang terlalu ketat dan menampakkan bentuk badan atau sebahagian badan wanita. Walaupun imej itu dalam bentuk animasi tetapi ia memberikan stigma dan sudut pandang bahawa wanita baik secara realitinya atau animasinya sangat terkait dengan elemen seksual. Sebaliknya, elemen kebolehan, skills dan teknik tidak menjadi antara elemen yang dipaparkan sebagai representasi kaum wanita.

Selain itu, watak wanita di dalam permainan dalam talian juga lebih bersifat 'supporting roles', manakala watak lelaki seringkali dijadikan sebagai watak utama dalam kebanyakan permainan dalam talian (Beasley \& Standley, 2002). Pembentukan imej, watak dan karakter seperti ini menyebabkan wujudnya kekangan terhadap pemain wanita untuk menonjol seperti pemain lelaki. Kekangan dari segi untuk mencapai ke ranking yang lebih tinggi atau meninggalkan peranan sebagai 'supporting roles' menjadi antara dilema kepada pemain wanita. Selain itu, stereotaip gender juga berlaku dalam pemilihan permainan dalam talian yang ingin seseorang wanita ceburi. Kebanyakan permainan berganda seperti DOTA, PUBG mahupun Mobile Legends, semuanya permainan yang agresif dan ganas. Kajian yang dijalankan oleh Nielsen (2009) mendapati bahawa pemain wanita lebih cenderung untuk memilih permainan dalam talian yang tidak terlalu agresif dan ganas. Permainan yang menggabung elemen tembak-menembak dan peranan berganda (multiple role) lebih banyak menarik minat kaum lelaki.

Sikap suka merendah-rendahkan kemampuan pemain wanita juga kerap berlaku. Bagi kebanyakan pemain lelaki, pemain wanita tidak secekap dan memiliki keupayaan tinggi acapkali pemain wanita terpaksa berhadapan dengan sentimen sedemikian (Witkowski, 2014). Ekoran daripada itu, terdapat pemain wanita yang sengaja tidak mendedahkan identiti gender mereka di dalam sesuatu permainan dalam talian (Witkowski, 2011). Sebaliknya, mereka lebih gemar memilih menggunakan nama seakan-akan lelaki supaya tidak menerima stereotaip gender. Permainan berperanan berganda (MMORPG) adalah permainan berpasukan. Kebanyakan pasukan hanya terdiri daripada satu gender sahaja. Namun demikian, terdapat juga pasukan yang memiliki campuran antara gender lelaki dan wanita. Pemain wanita yang berada dalam kumpulan campuran ini sering merasa tertekan terutama apabila pasukan mereka mengalami kekalahan. Hal ini kerana, beban kekalahan lazimnya akan terpikul di bahu mereka. Menjadi mangsa stigma dan label menjatuhkan reputasi pasukan (Kaye \& Pennington, 2016), ketidakupayaan mereka dan kekurangan 'skills' (Gray, 2012) dikatakan sebagai punca kekalahan pasukan. Justeru itu, pemain wanita lebih gemar membina kumpulan yang ahlinya terdiri daripada gender yang sama. Situasi ini 
boleh mengelakkan mereka menerima label negatif yang akhirnya memberi kesan emosi di kemudian hari.

\section{Kesan Stereotaip Gender}

Gangguan seksual boleh memberi kesan ke atas aspek emosi dan fizikal seseorang. Bukan sahaja dalam sukan tradisional, di dalam e-sukan juga gangguan seksual boleh berlaku. la secara tidak langsung boleh memberi kesan dari segi tekanan emosi (Koss, 1990), kepercayaan diri semakin merendah, marah dan kecewa (Brackenridge \& Walseth, 2002). Selain itu, stigma dan label yang menyatakan bahawa wanita tidak semahir lelaki dalam permainan di dalam talian juga menyebabkan wanita yang menerima label tersebut akhirnya tidak dapat melangkah jauh (Fox \& Tang, 2014) dalam industri e-sukan. Selanjutnya, adakalanya pemain wanita ini dikeluarkan daripada permainan atau digantikan dengan pemain lelaki kerana stigma lelaki adalah pemain yang lebih baik daripada wanita.

Kesan negatif terhasil daripada stereotaip gender ini juga mengakibatkan wanita sangat perlu bersusah payah untuk berada di dalam ranking tertinggi (Lowrie \& Jogensen, 2011) e-sukan baik di mana-mana negara sekalipun. Secara tidak langsung dari segi pembayaran gaji mahupun hadiah kemenangan juga akan berlakunya ketidaksamarataan antara pemain lelaki mahupun wanita. Secara purata, pemain wanita membawa hasil kemenangan sebanyak USD3,331.18 berbanding dengan purata jumlah hadiah kemenangan yang dikutip oleh pemain lelaki sebanyak USD443,276.80. Kajian yang dijalan oleh Entertainment Software Association (ESA) tersebut menunjukkan perbezaan sebanyak $751 \%$ (Shaw, 2012).

\section{METODOLOGI}

Kajian ini menggunakan pendekatan kualitatif untuk mendapatkan data dan maklumat. Oleh kerana kajian ini memfokuskan kepada isu stereotaip gender, pendekatan kualitatif dilihat merupakan satu pendekatan yang sangat sesuai digunapakai. Penulis boleh menanyakan soalan secara fleksibel kepada informan. Kaedah temu bual mendalam telah dilakukan terhadap tujuh orang informan. Walaupun pada awalnya penulis mensasarkan seramai 10 orang informan untuk ditemu bual, namun oleh kerana beberapa kekangan seperti jumlah pemain wanita aktif tidak terlalu ramai dan kesibukan mereka di dalam menyertai pelbagai pertandingan turut menghadkan penulis mendapatkan jumlah informan yang diingini.

Informan dipilih menggunakan kaedah bukan kebarangkalian iaitu persampelan bertujuan. Antara ciri-ciri yang ditetapkan oleh penulis adalah, pemain e-sukan wanita yang berusia lingkungan 18 hingga 30 tahun. Justifikasi memilih informan di dalam lingkungan umur ini adalah statistik menunjukkan bahawa kebanyakan pemain e-sukan adalah terdiri daripada mereka yang berumur dalam lingkungan tersebut. Selain itu, informan wanita yang aktif bermain permainan dalam talian dan bernaung di bawah kelab sukan tertentu. Pentingnya memilih informan yang berdaftar dengan sesuatu kelab e-sukan adalah kerana, dari segi konsep e-sukan itu sendiri iaitu, pemain yang mewakili sesuatu pasukan/kelab dalam satu-satu pertandingan. Selain itu, data daripada sumber sekunder turut dirujuk bagi mendapatkan maklumat yang lebih meluas. Hasil kajian dianalisis menggunakan kaedah tematik, iaitu penulis menyusun hasil rakaman temu bual dengan beberapa tema yang telah ditetapkan. Kesemua tema yang dibina khusus bagi menjawab isu kajian yang ingin dibincangkan. Data dipersembahkan secara deskriptif dan naratif. 
Profil Sosio-Demografi Informan

HASIL DAN PERBINCANGAN

Seramai tujuh orang informan telah ditemu bual di dalam kajian ini. Perincian mengenai latar belakang informan adalah seperti berikut:

\begin{tabular}{lccc} 
& Jadual 1: Profil Informan & \\
\hline Nama Samaran & Pasukan diwakili & $\begin{array}{c}\text { Umur } \\
\text { (tahun) }\end{array}$ & $\begin{array}{c}\text { Tempoh Terlibat di } \\
\text { dalam E-sukan }\end{array}$ \\
\hline Mojo & NED Esports & 21 & 2tahun \\
Karen & NED Esports & 20 & 3 tahun \\
Wenny & NED Esports & 21 & 2 tahun \\
Gigi & Weak Esports & 19 & 1tahun \\
Sarah & Weak Esports & 22 & 2tahun \\
Wispie & YoloPotato & 20 & 3tahun \\
Jenny & YoloPotato & 19 & 1tahun \\
\hline
\end{tabular}

Berdasarkan Jadual 1, kesemua informan berusia antara 19 tahun sehingga 22 tahun. Informan ini terdiri daripada tiga kelab e-sukan berdaftar iaitu NED Esports, Weak Esports dan YoloPotato. Dari segi pengalaman pula, Jenny dan Gigi merupakan dua orang informan yang memiliki pengalaman paling sedikit di dalam e-sukan iaitu selama setahun. Manakala, Mojo, Wenny dan Sarah telah melibatkan diri dalam e-sukan di Malaysia selama tempoh dua tahun. Pemain paling senior antara informan kajian adalah Karen dan Wispie, mereka berdua telah berkecimpung di dalam industri e-sukan Malaysia selama tiga tahun. Walaupun tempoh keterlibatan para informan masih di peringkat yang agak baharu iaitu antara setahun hingga tiga tahun, tetapi kesemua informan ini sebenarnya telah terlibat aktif dan mendapat pendedahan di dalam permainan 'video game' untuk jangka masa yang lama. Bagaimanapun, tempoh mereka menjadi seorang 'profesional gamers' itu masih di peringkat yang baharu.

\section{Penglibatan di dalam e-Sukan}

Sebelum melangkah ke isu berkenaan dengan stereotaip, adalah perlu untuk mengetahui terlebih dahulu bagaimanakah proses para informan boleh terlibat di dalam e-sukan. Majoriti informan menyatakan bahawa minat bermain 'video game' sejak di bangku sekolah menjadi pendorong utama mereka bergiat aktif dan akhirnya memilih e-sukan sebagai satu kerjaya. Walaubagaimanapun, Jenny yang merupakan informan termuda menambah:

"I memang minat main games semua ni, tapi dulu I main just sekadar sukasuka, nak hilangkan stress, nak full my leisure time. Never though I would end up being a profesional gamer. But I do see that you can make money within this industry" (Jenny).

Situasi tersebut menunjukkan bahawa bermain permainan video bukan lagi boleh dianggap sebagai satu benda yang negatif semata-mata. Walaupun banyak kajian lepas mengaitkan keterlibatan dalam permainan video ini menyumbang kepada ketagihan (Gentile et al., 2011; Ozcan \& Buzlu, 2007), kelalaian pelajaran (Griffiths, 2010), mendorong pemainnya menjadi agresif dan ganas (Lebenbauer-Baum \& Fohringer, 2015) dan boleh juga mengakibatkan masalah kesihatan (Young, 2009). Kini, permainan video juga menawarkan 
banyak kebaikan buat pemainnya. Salah satu daripada kebaikan tersebut adalah pulangan wang yang lumayan hasil daripada gaji sebagai seorang pemain profesional atau hadiah kemenangan daripada kejohanan-kejohanan yang disertai.

Selain daripada minat atau hobi, antara faktor yang mendorong penglibatan informan di dalam e-sukan ialah pengaruh daripada rakan sebaya. Rakan sebaya merupakan agen sosialisasi penting yang boleh menjadi daya penarik atau penolak kepada sesuatu tingkah laku individu lain. Menurut Karen:

"I dulu tak berapa pandai sangat main games ni. I main games pun yang simple-simple saje macam candy crush, arcade games macam tu. But, I have a few friends yang memang terer main games. Especially games yang strategik like MOBA, Headstone. I mula tak faham macam mana main that games. Tapi / tengok kawan-kawan I main, memang tak faham tapi bila menang tu memang seronok, you rasa sangat puas. Dari situ, I minta my friends ajar I macam mana nak main" (Karen).

Informan Karen menegaskan bahawa kawan-kawan rapat memainkan peranan penting yang mendorong untuk belajar bermain MMORPG. Jika dahulu hanya pandai bermain permainan video yang santai, tetapi apabila mula didedahkan dengan permainan MMORPG yang lebih strategi dan skills, akhirnya timbul minat untuk mempelajari permainan tersebut. Informan Wispie turut bersetuju dengan kenyataan Karen dan turut menambah:

\footnotetext{
"Permainan peranan berganda macam PUBG, MOBA atau DOTA memang nampak susah. Yang susahnya adalah you kena faham bagaimana to play the game, then you have to come out with the strategy how to win the game. Komunikasi dengan teammate sangat penting. Sebab MMORPG punya game ni adalah permainan berkumpulan. Kalau you tak ada komunikasi dan persefahaman yang baik dengan ahli, memang you takkan menang that game" (Wispie).
}

Komunikasi bersama ahli pasukan menjadi senjata utama untuk memenangi sesuatu perlawanan. Permainan MMORPG ini sifatnya adalah permainan berkumpulan. Setiap pemain mempunyai peranan tertentu untuk memastikan pasukan mencapai kemenangan (Yee, 2006). Ahli pasukan bukan sahaja dianggap sebagai rakan-rakan tetapi lebih daripada itu. Hal ini kerana, selain aspek komunikasi, kepercayaan (Huang, Hood \& Woo, 2013) sesama ahli pasukan adalah sangat perlu di dalam permainan ini. Jika tiadanya kepercayaan terhadap sesama pasukan maka adalah sukar bagi sesuatu pasukan meraih kemenangan.

Faktor lain yang mendorong penglibatan informan di dalam e-sukan ialah media massa terutamanya media sosial. Peranan media sosial sangat penting kini. Hal ini kerana, interaksi sosial adakalanya lebih banyak berlaku di media sosial secara 'virtual' berbanding dengan bersemuka. Informan menyatakan bahawa iklan-iklan yang keluar di Facebook dan YouTube terutamanya berkaitan dengan permainan dalam talian menarik minat mereka. Menurut Gigi pula: 


\begin{abstract}
"Saya memang dah lama main games ni semua. Tapi just for fun atau compete dengan kawan-kawan saja. Memang tak ada niat mau jadi profesional. Sebab memang tengok tak ramai girls yang main pro. Semua lelaki. Tapi bila ada satu kali saya tengok YouTube nama ada ramai girls yang main game streaming live. Kemudian saya start follow diorang. Nampak menarik and saya dapat tahu juga streaming macam tu pun you dapat payment banyak".
\end{abstract}

Melalui platform YouTube misalnya, terdapat satu medium live streaming ketika bermain 'games'. Kaedah ini adalah bermaksud permainan anda disaksikan oleh ratusan mungkin ribuan orang. Penonton boleh memberi komen ketika seseorang pemain bermain dan pemain turut boleh berinteraksi dengan penonton (Webster, 2013). Situasi ini menjadi salah satu daya tarikan kepada individu di luar sana yang berminat untuk menjadikan 'gamers' sebagai satu kerjaya profesional. Seperti yang dinyatakan oleh Gigi, bahawa kaedah penstrimin langsung boleh menjana pendapatan yang lumayan bergantung kepada berapa ramai penonton yang menonton anda ketika bermain dan berapa lama seseorang pemain mampu bertahan dalam permainan tersebut.

\title{
Stereotaip Gender yang Dihadapi
}

Seperti yang dinyatakan sebelum ini, industri e-sukan sememangnya dipelopori oleh lelaki. Walaupun terdapat sebilangan pemain wanita yang berjaya meloloskan diri ke dalam industri ini, namun ia bukanlah satu perjalanan yang mudah. Kesemua informan mengakui bahawa mereka pernah berhadapan dengan isu stereotaip gender terutamanya ketika awal pembabitan mereka di dalam e-sukan. Bahkan, walaupun kesemua informan kini telah memiliki pengalaman selama satu hingga tiga tahun di dalam industri ini, namun stereotaip gender masih juga belum terhapus sepenuhnya. Menurut kesemua informan kajian, faktor jantina merupakan penyebab utama mereka distereotaip. Hal ini kerana, sosialisasi gender (Ferrante, 2011) yang diamalkan dan peranan budaya dalam masyarakat Malaysia khususnya membezakan antara apa yang boleh dilakukan oleh wanita dengan lelaki.

"You tahulah, games ini semua permainan lelaki. Jadinya bila perempuan macam you mula main, memang akan ada yang cakap something pada you. I pernah kena cakap..ala perempuan tak pandai lah main games, you elok pergi dapur belajar masak. Itu lebih sesuai" (Sarah).

Pengkelasan mengenai apa yang boleh dan tidak boleh dilakukan oleh seseorang wanita menyebabkan informan turut mengalami stigma bahawa oleh kerana informan seorang wanita, maka informan dianggap sebagai tidak sesuai untuk bermain permainan video. Menurut Wenny pula:

"I pun pernah kena kutuk dengan lelaki. Bila I sign up for one competetion, my rival was a male. Then, he said.. you know how to play meh?".

Situasi tersebut menunjukkan bahawa, secara tidak langsung pemain lelaki iaitu pihak lawan memandang rendah kepada kemampuan informan di dalam pertandingan. Hasil kajian ini selari dengan yang ditemui oleh Beasley dan Standley (2002) yang 
menyatakan bahawa atlet e-sukan wanita seringkali diragui kemampuan dan kebolehan mereka bermain oleh pihak lawan terutamanya. Selanjutnya, Hartmann dan Klimmt (2006) menambah bahawa, adakalanya pihak lawan terlampau memandang rendah kepada pemain wanita ini sehinggakan mereka bermain sambil lewa. Apabila skor mereka telah dipintas oleh pemain wanita, maka pemain lelaki ini mula memainkan sentimen gender sebagai usaha provokasi kepada pihak lawan agar hilang fokus kepada permainan.

Bukan itu sahaja, para informan turut menyatakan antara stereotaip lain yang dialami mereka ialah tidak mendapat penghormatan sama seperti apa yang diterima oleh pemain lelaki. Walaupun mereka merasakan bahawa diri mereka mempunyai kebolehan untuk bermain setanding dengan lelaki tetapi untuk berada separas dengan lelaki di dalam industri ini agak susah. Perkara ini dinyatakan oleh Wispie:

"I join this industry dah tiga tahun lebih. I dah masuk banyak competetion, ada yang I menang top place juga tau. Tapi, still I rasa I did not get any much attention and respect from the others. Especially from the male".

Jika informan berjaya di dalam pertandingan, mereka tetap merasakan bahawa mereka tidak mendapat pengiktirafan dan penghormatan seperti lelaki. Ada ketikanya terdapat ayat sinis yang dilontarkan kepada informan bahawa kemenangan beliau hanyalah faktor nasib atau tuah. Selain itu, dari aspek komunikasi juga berlakunya masalah kepada pemain wanita. Isu komunikasi paling ketara apabila berada dalam pasukan campuran antara lelaki dan wanita. Seperti yang pernah dialami oleh Mojo:

"Sebelum I join my team sekarang, I dah pernah join satu team dulu. That was my first team bila I join e-sports. Dalam tu semua players adalah lelaki except me. But, I feel that I being discriminate dan susah nak communicate dengan diorang you tahu. Komunikasi dalam pasukan tu not quite well ".

Mojo sebelum ini pernah menganggotai pasukan yang ahlinya campuran antara lelaki dan wanita. Di dalam pasukan terdahulu, Mojo satu-satunya pemain wanita di dalam pasukan. Seperti dinyatakan sebelum ini permainan video berperanan berganda ini, komunikasi antara ahli pasukan sangat penting. Strategi perlu dirangka dengan teliti, setiap pemain perlu mengetahui peranan masing-masing, siapa yang ingin menjadi 'main role' siapa yang akan menjadi 'suporting roles'. Oleh kerana, Mojo seorang wanita dan usia yang masih muda, kadangkala cadangan yang beliau utarakan untuk kebaikan kumpulan tidak diterima oleh ahli-ahli lain. Mereka seolah merasakan bahawa lelaki lebih pandai bermain permainan MMORPG berbanding wanita. Disebabkan faktor ini juga yang menyebabkan Mojo memilih untuk keluar daripada pasukan lamanya dan memilih untuk menganggotai NED Esports yang dianggotai oleh semua pemain wanita.

"Bila I tukar ke team perempuan I feel more relieve, no more stress. Because among female players you have that bonding, you naik sama-sama you turun sama-sama. That's the most I like" (Mojo).

Apabila berada di dalam kumpulan yang sama jantinanya, beliau merasakan bahawa stress ketika berada dalam pasukan sudah berkurangan. Komunikasi semakin lancar dan boleh bersama-sama dengan ahli pasukan lain merangka strategi untuk memastikan 
kemenangan dalam setiap pertandingan yang disertai. Mereka juga adalakanya memfokuskan menyertai pertandingan yang memfoksukan kepada pemain e-sukan wanita sahaja. la lebih menyeronokkan kerana tiadanya stereotaip atau diskriminasi gender yang akan dilemparkan kepada mereka.

Antara stereotaip lain yang pernah dilalui oleh informan kajian adalah, mereka lazimnya akan diberikan watak pembantu (supporting role) di dalam pertandingan. Manakala watak utama masih didominasi oleh pemain lelaki. Situasi ini mempunyai kaitan dengan stigma bahawa wanita bukanlah pemain yang baik. Justeru itu lelaki sentiasa diberikan peranan memegang watak utama (Ivory, 2006). Menurut informan, jika beliau telah berada di dalam pasukan untuk satu jangka masa yang lama, dan pengurusan boleh melihat perkembangan kebolehan tetapi masih meragui untuk meletakkan beliau sebagai pemain utama ia didorong oleh rasa sangsi dengan kebolehan beliau dan meragui samada beliau mampu membawa kemenangan atau kekalahan kepada pasukan kelak. Walhal, pemain lelaki yang memegang watak utama turut ada ketikanya di dalam satu pertandingan, tidak dapat beraksi dengan baik tetapi masih diberi peluang untuk memegang watak utama di pertandingan berikutnya. Manakala, beliau masih terus-terusan diberikan peranan sebagai pembantu bagi mengalihkan tumpuan pihak lawan daripada 'membunuh watak utama'.

Situasi ini secara tidak langsung telah menyekat peluang dan ruang pemain wanita untuk mengembangkan potensi mereka di dalam sesuatu permainan dan pertandingan yang disertai. Lebih teruk lagi, ia akan membunuh kepercayaan diri mereka bahawa mereka sememangnya tidak mempunyai kebolehan sama seperti pemain lelaki. Jika situasi ini berterusan, tidak mustahil ramai pemain wanita akan mengundurkan diri dari industri ini kelak.

Wanita dan 'sexism' atau simbol seks adalah satu perumpamaan yang sangat sinonim. Begitu juga berlaku di dalam e-sukan, walaupun ia adalah permainan secara virtual namun isu berkenaan sexism masih berlaku. Informan menyatakan bahawa mereka kadangkala tidak dipandang dari segi keupayaan mereka di dalam sesuatu permainan tetapi mereka lebih dipandang dari aspek sexism. Gigi menambah:

"Walau you masa pertandingan tak pakai sexy pun. You pakai team punya attire very modest actually tetapi masih lagi I terima komen tentang sexy oleh lelaki, macam wow you looks so sexy in this watak dan diorang ada tanya sebetulnya in realiti either I seksi or not".

Hal ini kerana pemain wanita sering diberikan watak pembantu iaitu watak animasi wanita yang lemah dan perlu diselamatkan oleh ahli pasukan. Bagi imej animasi wanita seperti ini, lazimnya adalah pakaian yang seksi, menunjukkan bentuk badan dan kulit yang terdedah (Fox \& Tang 2016). Bagi sesetengah lelaki, imej watak yang dimainkan oleh informan menggambarkan imej realiti informan. Justeru itu, adakalanya informan diberikan komen berbau sexism walau realitinya mereka bukan dikategorikan sebagai seorang wanita yang seksi. Imej yang dimainkan mereka mempengaruhi pihak lawan melontarkan pandangan sedemikian. Oleh yang demikian, pemain wanita seharusnya tidak hanya dibenarkan memegang watak pembantu untuk jangka masa yang lama kerana ingin mengelakkan situasi seperti ini berterusan. Komen-komen berbaur seksi ini akhirnya boleh 
dikategorikan sebagai satu bentuk gangguan seksual terhadap pemain wanita (Fox et al., 2015).

"I agree, that's why dulu masa I mula-mula join sukan ni I guna nama yang tak represent sangat that I am female players. Sebab I nak avoid kena komen-komen sexism atau I tak nak kena stigma just because I am a female" (Wenny).

Antara langkah yang pernah diambil oleh informan bagi mengelakkan mereka dilabel dan diberikan komen berbaur sexism adalah dengan tidak menggunakan nama watak yang menjurus ke arah nama wanita. Wenny misalnya pada awal pembabitan dalam e-sukan lebih gemar menggunakan nama yang tidak menggambarkan beliau adalah pemain wanita. Apabila menggunakan nama seperti Kingston, Richminds pihak lawan tidak mengetahui bahawa beliau adalah wanita apatah lagi jika beliau tidak memegang watak sebagai wanita. Dengan itu, beliau merasakan bahawa tiada komen berunsur stereotaip gender yang dikenakan terhadap beliau ketika beliau menggunakan nama tersebut.

Informan turut menyatakan bahawa oleh kerana mereka adalah wanita, mereka juga dinafikan hak untuk bermain dalam pertandingan yang besar dan menawarkan hadiah yang lumayan. Pertandingan e-sukan mempunyai banyak peringkat, dari peringkat liga kelabkelab sehingga ke peringkat antarabangsa. Perbezaan peringkat ini secara langsung menunjukkan perbezaan hadiah kemenangan yang bakal diperoleh. Jika perlawanan di peringkat antarabangsa, hadiah kemenangan lazimnya akan di bayar dalam USD. Menurut informan Karen:

"In this industry, we all female players normally susah nak represent country ke tournament international. You have to be excellent, good is not enough because they will always comparing you and the boys".

Pemain wanita perlu benar-benar cemerlang di dalam permainan jika mahu dihantar menyertai pertandingan di luar negara. Apatah lagi jika mewakili negara, pemilihan menjadi sangat rigid iaitu hanya pemain yang cemerlang di dalam negara, cemerlang di luar negara yang akan mendapat peluang mewakili negara ke kejohanan antarabangsa. Oleh sebab itu, jika dilihat dari statistik kejayaan pemain negara di kejohanan antarabangsa kesemuanya adalah pemain lelaki. Peluang sama rata dengan pemain lelaki dilihat oleh informan sebagai sesuatu yang susah untuk dicapai di dalam industri ini.

\section{KESIMPULAN}

Malaysia bercita-cita ingin menjadi hub bagi e-sukan peringkat Asia. Oleh yang demikian banyak sekali pendedahan serta kejohanan berkaitan telah dilancarkan. Suntikan dana oleh pihak Kementerian Belia dan Sukan turut menunjukkan komitmen negara mencapai matlamat tersebut. Walaubagaimanapun, semua usaha tersebut dilihat sukar dicapai jika isu gender masih menjadi isu besar dalam industri e-sukan di Malaysia. Walaupun pada dasarkan, pihak kementerian dan pihak penganjur pertandingan mahupun kelab mengalualukan kemasukan wanita sebagai salah satu pemegang taruh di dalam e-sukan di Malaysia, namun ia tidak semudah yang disangka. Pemain e-sukan wanita terpaksa berhadapan dengan pelbagai cabaran yang bersangkutan dengan isu stereotaip gender sebelum dan juga semasa mereka memilih menjadi sebahagian daripada e-sukan. 
Sememangnya tidak boleh dinafikan bahawa pemain permainan video wanita memiliki kebolehan dan keupayaan mereka tersendiri. Terdapat ramai pemain wanita yang berjaya namun kejayaan tersebut dilalui dengan bermacam kepayahan. Pihak bertanggungjawab seperti pihak Kementerian Belia dan Sukan, pihak Persatuan e-sports Malaysia serta pengurusan kelab e-sukan perlu membuka mata mengenai isu berkaitan stereotaip gender ini. Peluang sama rata kepada pemain wanita dan lelaki seharusnya tidak boleh dikompromi. Jika tidak, mungkin satu hari nanti jumlah penyertaan wanita di dalam esukan semakin berkurangan kerana golongan ini tidak dapat menangani stereotaip yang dilemparkan terhadap mereka. Boleh disimpulkan bahawa, kini walaupun terdapat stereotaip gender terhadap pemain wanita, mereka masih boleh kekal di dalam industri ini kerana minat mereka yang sangat mendalam terhadap permainan video. Namun demikian, dibimbangi kelak, minat ini juga boleh luntur jika ketaksamaan layanan oleh golongan lelaki berlaku di dalam industri ini.

\section{PENGHARGAAN}

Artikel ini adalah sebahagian daripada hasil kajian dibawah dana Kementerian Pendidikan Malaysia (KPM) iaitu FRGS/1/2019/SS06/UKM/02/5.

\section{BIODATA}

Nur Hafizah Yusoff adalah pensyarah kanan di program Antropologi dan Sosiologi di bawah Pusat Kajian Pembangunan, Sosial dan Persekitaran (SEEDS), Fakulti Sains Sosial dan Kemanusiaan (FSSK), UKM. Email: nur_hafizah@ukm.edu.my

Zurinah Tahir adalah pensyarah kanan di program Sains Pembangunan di bawah Pusat Kajian Pembangunan, Sosial dan Persekitaran (SEEDS), Fakulti Sains Sosial dan Kemanusiaan (FSSK), UKM. Email: zurinahtahir@ukm.edu.my

Novel Anak Lyndon adalah Profesor Madya di program Antropologi dan Sosiologi di bawah Pusat Kajian Pembangunan, Sosial dan Persekitaran (SEEDS), Fakulti Sains Sosial dan Kemanusiaan (FSSK), UKM. Email: novel@ukm.edu.my

Norhafizah Abu Hasan adalah pensyarah Fakulti Ekonomi dan Pengurusan, UKM. Email: norhafizah1@ukm.edu.my

Yuza Haiqal Mohd Yunus merupakan pelajar sarjana falsafah di program Antropologi dan Sosiologi di bawah Pusat Kajian Pembangunan, Sosial dan Persekitaran (SEEDS), Fakulti Sains Sosial dan Kemanusiaan (FSSK), UKM. Email: yuzahaiqal@yahoo.com 


\section{RUJUKAN}

Beasley, B., \& Standley, T. C. (2002). Shirts vs. skins: Clothing as indicator of gender role 2.0 applications for learning in higher education. The Internet and Higher Education, 16, 57-65.

Blumberg, F. C., \& Sokol, L. M. (2004). Boys' and girls' use of cognitive strategy when learning Debunking the gender performance gap in two massively multiplayer online games. In A. Paludi (Ed.), Ivory power: Sexual harassment on campus (pp. 73-92). United States: Albany.

Bonanno, P., \& Kommers, P. A. M. (2008). Exploring the influence of gender and gaming competence on attitudes towards using instructional games. British Journal of Educational Technology, 39(1), 97-109. https://doi.org/10.1111/j.14678535.2007.00732.x

Bradmore, \& Magus. (December 7, 2016). 2016 League of Legends world championship by the numbers. LoL Esports. Retrieved on March 5, 2017, from http://www.lolesports.com/en_US/articles/2016-league-legends-world championship numbers

Chan, E. Y. (2008). Females' video game playing motivation and performance: Examining females' gaming performance. Computers in Human Behavior, 59, 202-209.

Chikhani, R. (October 31, 2015). The history of gaming: An evolving community. Techcrunch. Retrieved on April 29, 2019, from https://techcrunch.com/2015/10/31/the-history-ofgaming-anevolving-community/

Christopher, C. (2014). Wait, when did playing video games become a sport?. Little Utopia. Retrieved on 23 October, 2019, from https://littleutopiamag.com/2014/12/12/videogames-become sport/

Edwards, T. F. (April 30, 2013). ESports: A brief history. Adanai. Retrieved on March 7, 2019, from http://adanai.com/esports/

Emma Mohamad, \& Nur Hazwani Ahmad Damanhuri. (2019). Etika pemimpin pendapat kesihatan wanita di Instagram. Jurnal Komunikasi: Malaysian Journal of Communication, 35(4), 193-210.

Everson, J. (2013). Why do MOBA's make such good eSports games? Game Skinny. Retrieved on March 06, 2017, from http://www.gameskinny.com/avpgu/why-domobas-make-suchgood-esports-games

Ferrante, J. (2011). Seeing sociology: An introduction. United Kingdom: Cengage Learning.

Fox, J., \& Tang, W. Y. (2014). Sexism in online video games: The role of conformity to masculine, gender stereotypes and competence goals (PhD, Dissertation, University of Southern California).

Fox, J., \& Tang, W. Y. (2016). Women's experience with general and sexual harassment in online video games: Rumination, organizational responsiveness, withdrawal, and coping strategies. New Media Soc., 1, 1-18.

Fox, J., Ralston, R., Cooper, C., \& Jones, K. (2015). Sexualized avatars lead to women's selfobjectification and acceptance of rape myths. Psychol. Women Q., 39, 349-362.

Gray, K. L. (2012). Deviant bodies, stigmatized identities, and racist acts: Examining the experiences of African-American gamers in Xbox live. New Review of Hypermedia and Multimedia, 18(4), 261-276. https://doi.org/10.1080/13614568.2012.746740

Griffiths, M. (2010). Online videp gaming: What should educational psychologists know?. Educational Psychology in Practice, 26(1), 35-40. 
Hamari, J. (2013). Transforming homo Economicus into Homo Ludens: A field experiment on gamification in a utilitarian peer-to-peer trading service. Electronic Commerce Research and Applications, 12(4), 236-245.

Hamari, J., \& Sjöblom, M. (2017). What is eSports and why do people watch it? Internet games. Journal of Computer-Mediated Communication, 11(4), 910-931.

Hartmann, T., \& Klimmt, C. (2006). Gender and computer games: Exploring females' dislikes. Mass Communication and Society, 9(1), 103-114.

Hayes, E. (2007). Gendered identities at play: Case studies of two women playing Morrowind. Games and Culture, 2(1), 2-23. https://doi.org/10.1177/1555412006294768

Huang, W. H. D., Hood, D. W., \& Yoo, S. J. (2013). Gender divide and acceptance of collaborative Web. Multimedia, 18(4), 261-276. https://doi.org/10.1080/13614568.2012.746740

Ivory, J. D. (2006). Still a man's game: Gender representation in online reviews of video. Journal of Computer-Mediated Communication, 21(4), 312-329.

Kaye, L. K., \& Pennington, C. R. (2016). "Girls can't play": The effects of stereotype threat on to play video games. The Journal of General Psychology, 131(2), 151-158.

Koss, M. P. (1990). Changed lives: The psychological impact of sexual harassment. In M. A. Paludi (Ed.), Ivory power: Sexual harassment on campus (SUNY series in the psychology of women) (p. 73-92). NY: State University of New York Press.

Lehenbauer-Baum, M., \& Fohringer, M. (2015). Towards classification criteria for internet gaming disorder: Debunking differences between addiction and high engagement in a German sample of World of Warcraft players. Computers in Human Behavior, 45,345351.

Lowrie, T., \& Jorgensen, R. (2011). Gender differences in students' mathematics game playing. Computers \& Education, 57(4), 2244-2248.

Lynch, A. (May 06, 2016). Tracing the 70-year history of video games becoming eSports. Fox Sports. Retrieved on Jan 7, 2020, from http://www.foxsports.com/buzzer/story/esportsexplainer-league-of-legends-heroesof-the-storm-hearthstone-cs-go-dreamhack-050616

Milne, G. R., \& McDonald, M. A. (1999). Sport marketing: Managing the exchange process. Sudbury, MA: Jones and Bartlett.

Mohd Azul Mohamad Salleh, Za-Edah Ekhwan, \& Ali Salman. (2019). Mudah guna dan manfaat aplikasi WhatsApp terhadap hubungan antara peribadi masyarakat dan polis. Jurnal Komunikasi: Malaysian Journal of Communication, 35(4), 135-154.

Mohd. Azul Mohamad Salleh, \& Nurul Madiha Mohd. Ilham. (2017). Pengalaman dan kesedaran pengguna dewasa terhadap isu pengawasan di media sosial. Jurnal Komunikasi: Malaysian Journal of Communication, 33(1), 502-514.

Nielsen. (2009). Insights on casual games: Analysis of casual games for the PC. USA: Author.

Ozlan N. K., \& Buzlu, S. (2007). Internet use and its relation with the psychosocial situation for sample of university students. Cyberpsychology and Behavior, 10(6),767-772. https://doi.org/10.1089/cpb.2007.9953

Ray, S. G. (2004). Gender inclusive game design: Expanding the market. Hingham: MA.

Ruvalcaba, O., Shulze, J., Kim, A., Berzenski, S. R., \& Otten, M.P. (2018). Women's experiences in esports: Gendered differences in peer and spectator feedback during competitive video game play. Journal of Sport and Social Issues, 42(4), 295-311. 
Shaw, A. (2012). Do you identify as a gamer? Gender, race, sexuality, and gamer identity. News Media and Society, 14(1), 28-44.

Shen, C., Ratan, R., Cai, Y. D., \& Leavitt, A. (2016). Do men advance faster than women? Stereotyping in video games. Mass Communication and Society, 5, 279-293.

Wagner. M. G. (2006). On the scientific relevance of e-sports. Proceedings of the 2006 International Conference on Internet Computing and Conference on Computer Game Development (pp. 437-440). Las Vegas: CSREA Press.

Webster, A. (2013). Don't die: Live streaming turns video game speed runs into a spectator sport. The Verge. Retrieved on December 23, 2019, from http://www.theverge.com/2013/1/21/3900406/video-gamespeedruns-as-livespectator-sport

Witkowski, E. (2014, October). Girl gamers? Player and institutional orientations towards women's participation in and around e-sports. Proceedings of the Internet Research 15, The 15th Annual Meeting of the Association of Internet Researchers, Daegu, Korea.

Yee, N. (2006). The demographics, motivations and derived experiences of users of massively-multiuser online graphical environments. Presence: Teleoperators and Virtual Environments, 15(3), 309-329.

Yee, N. (2006). The demographics, motivations and derived experiences of users of massively-multiuser online graphical environments. Presence: Teleoperators and Virtual Environments, 15(3), 309- 329.

Young, K. S. (2009). Understanding online gaming addiction and treatment issues for adolescents. The American Journal of Family Therapy, 37, 355-372. 